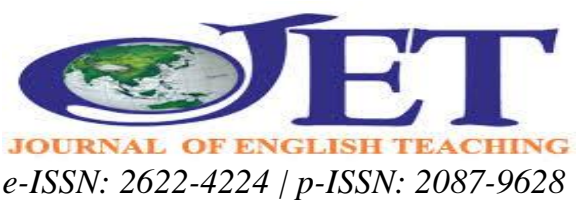

\title{
Developing Students' Higher Order Thinking Skills (HOTS) in Reading: English Teachers' Strategies in Selected Junior High Schools
}

\author{
Bernadeta Siska Indriyana \\ bernadetasiska28@gmail.com \\ English Education Master's Program, \\ Sanata Dharma University \\ Paulus Kuswandono \\ kus@usd.ac.id \\ English Education Master's Program, \\ Sanata Dharma University
}

DOI: http://dx.doi.org/10.33541/jet.v5i3.1313

\begin{abstract}
The 2013 curriculum in Indonesia mandates that teachers should develop students' Higher Order Thinking Skills (HOTS). One of the learning goals through HOTS is to make sure that students can analyze, evaluate, and create their knowledge. However, studies on HOTS issues in English learning, particularly in reading skills, are still very limited. Therefore, this study aimed at describing the teachers' strategies in developing HOTS in teaching reading skills. The researcher used a mixed-method, as it is relevant to the methodology needed in this study. The participants were 22 English teachers of Junior High Schools in Yogyakarta. The data were collected through questionnaires, observations, and interviews. The findings indicated that the strategies by the teachers to develop HOTS were as follows: (1) asking divergent questions to the students, (2) using group discussions, (3) informing learning objectives to the students, (3) giving feedback to invite the students to review, refine, and improve understanding about learning materials, and (5) giving motivation to the students to think critically. The recommendation for further study is also discussed.
\end{abstract}

Keywords: HOTS, reading skill, teachers' strategies

\section{INTRODUCTION}

In Indonesia, English teaching strategies using HOTS are mandatory. One of the learning goals through HOTS is to make sure that students can analyze, evaluate, and create their knowledge (Ariyana, Bestary, \& Mohandas, 2018). In the 2013 curriculum, teachers should develop higher-order thinking skills. As Seman, Yusoff, \& Embong (2017) describe, HOTS is the level of thinking that emphasizes the application of knowledge that has been received, the examination of reflections, problem-solving, decision making and formulating new things.

According to Heong et al (2011), teachers should develop students' higher-order thinking skills required to think broadly to discover a new challenge. HOTS allows someone to apply new knowledge and information in order to be able to respond in a new condition. Brookhart (2010) states that HOTS is conceived as the top 
end of Bloom's cognitive taxonomy. Being able to think means students can implement the skill and knowledge they develop during their learning of a new topic. Limbach \& Waugh (2010) propose five steps to develop the ability to think critically, namely determining the learning objective of reading class, teaching through questioning, ordering students to practice, reviewing refining and improving understanding, and practicing feedback and assessing learning. All these five steps should be integrated to optimize critical thinking.

Nowadays reading ability becomes the most important language skill for English as a Foreign Language (EFL) or second language (ESL) students in academic contexts (Grabe, 2010). As shown below, reading comprehension, growth of fluency, and enjoyment in reading should go hand in hand and must be built up together over time through training. According to Nuary (2015), the cultivation of good readability can involve extensive struggle for many students in EFL context, particularly for those who are still at the low level of understanding. This condition can substantially contribute to a lack of enjoyment and less learning that will engender lower understanding and fluency. This precisely explains why a growing number of teachers and researchers have paid attention to the extensive reading program, especially since the 1990s (Grabe, 2010). Day and Bamford (2002) suggest that the first successful experience of the students in extensive reading leads to a finding, which is enjoyable and rewarding in the second language. This stimulates the development of positive reading approaches, which are reinforced in subsequent extensive readings (Day \& Bamford, 2002, p. 30).

The link between reading skills and critical thinking has been highlighted by cognitive psychology. Critical thinking can be taken as a means by which schema can be activated or created. According to Aloqaili (2012), the schema has an interactive relationship with reading comprehension between the prior knowledge of readers and the read text. Readers sometimes come to a different understanding based on their experience. As Aloqaili (2012) argues, having reading as a critical thinking act becomes more manageable if some of the readings are recognized as automatic and essential, but not enough to develop an understanding of the text. The introduction of HOTS to tackle reading problems can facilitate students to develop their understanding of texts.

There are some relevant studies related to the teacher strategy to develop HOTS in teaching reading skills. Samelian's (2017) conducted a classroom action research (CAR) to investigate how she can improve fifth-graders' reading comprehension using critical thinking and higher-order questioning research. The results showed that higher-order questioning and critical thinking can improve understanding of critical thinking skills and help students engage in high-level thinking to strengthen their reading comprehension. Nuary's (2015) study involved the seventh grade students of SMP Murni 1 Surakarta to explore the implementation of discussion in teaching reading. The results showed that the discussion process consisted of pre-discussion activities and post-discussion activities. The activity was based on discussion, small group discussion, and classroom discussion. In implementing the technique, the teacher faced problems with technology, class administration, scheduling, and students. Additionally, Kulekci \& Kumlu (2015) conducted another study on critical thinking skills development in English Language Teaching classes through novels. It was intended to pave the way for students by learning novels to achieve critical thinking skills. The results indicated that the development and the use of reading literature as an incentive to think critically are essential objects in higher education and are an easy approach. 
Based on the requirement to apply HOTS in the 2013 curriculum, many teachers are still confused about developing HOTS to teach reading. They said that the teachers did not have enough understanding of HOTS. Then, the school did not provide training for developing HOTS for teachers. Teachers, therefore, need some strategies to teach using HOTS. As Kistner, Rakoczy, Otto, \& Klieme (2015) state, teaching-learning strategy is one major aspect of the consistently claimed promotion of self-regulated learning in the classroom.

Considering the background above, the researchers were interested to investigate the teachers' strategies using HOTS, especially in reading skills. Conforming to the previous studies and contexts, this study proposes one research question as follows: "What are the teachers' strategies for developing Higher Order Thinking Skills in teaching reading skills?"

\section{LITERATURE REVIEW \\ Higher Order Thinking Skills}

HOTS is a perplexing term and can be described as the use of critical and creative thinking so that one can solve difficult issues (Yeung, 2016). Based on the observation, many English teachers did not understand the concept of HOTS. Increasing the capacity to think critically of young students is one of the major goals of the latest education reform in Hong Kong (Leung, 2008). Lee \& Lai (2017) point out that to ask students open-ended questions could lead them to make comparisons, provide justification or conduct inquiry-based on prior knowledge. It helps them to develop the ability to think critically. In addition to successful inquiry approaches, Leung (2008) suggests the use of active learning techniques to encourage students' skills in higher-order thinking.

Bloom's taxonomy is an academic model often used to assess the lessons and learning results (Alsowat, 2016). The revised Bloom's Taxonomy consists of six levels: remembering, understanding, applying, evaluating and creating. The highest level of the cognitive domain is creating. Analyzing, evaluating and creating are the highest three levels of Bloom's Taxonomy. Those are known as HOTS. Educators have noticed in the past two decades that HOTS did not immediately exist to most students so that certain HOTS should be taught directly and explicitly at various points during a semester (Williams, 2015).

Barkhuizen (2017) recommends what she called a "dialog-thinking reading lesson" when teaching critical thinking in the reading context. The classes required EFL students to go back to the text to clarify details, consider a variety of interpretations, find proof to support their interpretations and evaluate competing interpretations. As EFL learners discussed, Arnuphab (2007) has them argue for or against every viewpoint, conviction or conclusion. Barkhuizen (2017) indicates students also needed to evaluate reasoning skills and critical thinking, not only the teacher. According to Alsowat (2016), teachers should help students understand their prerogatives, create open-ended questions, help students establish evaluation criteria, and provide students with clear arguments and evidence to support their opinions. Savich (2009) promotes the use of many texts in teaching critical thinking. Through several texts, she indicated that students are more likely to question, identify discrepancies in various accounts, view different perspectives on issues, assess assumptions, and search for consensus across sources before making a judgment. 


\section{Strategies for Improving Reading Comprehension Using HOTS}

HOTS is linked to an increased understanding of reading for junior high school students (Marina, Acosta, \& Ferri, 2015). The students have been able to increase reading comprehension by using some strategies such as graphical organizers, higher thought techniques for questioning and collaborative groups. Peña \& Cañón (2008) argue to develop HOTS through cooperative work and questioning for junior high school students in reading comprehension. These are some skills that have been split into less and more nuanced learning objectives; information, comprehension, usage, modeling, analysis, and assessment. Teachers should integrate and develop the skills to enable students to think at a learning level. For understanding in learning, students can retell or translate in writing or orally what they understand in their own words, sort out, compare and contrast information, and interpret it.

Strategies to develop comprehension in this study are asking divergent questions to the students, using group discussions, informing learning objectives to the students, giving feedback to invite the students to review, refine, and improve understanding about learning materials, and giving motivation to the students to think critically (Marina et al., 2015). At the beginning of the class, teachers inform learning objectives to students. The teacher used this step to apply HOTS in teaching the reading skill to develop their critical thinking in brainstorming, analyzing, and creating the text. Limbach \& Waugh (2010) state about teachers determining learning objectives to improve critical thinking. Then, Harvey \& Goudvis (2017) describe that the process of questioning requires the readers to ask themselves questions to develop meaning, increase understanding, find answers, solve problems, find information and discover new information. Teachers used questions and answer strategies to review, examine learning, and challenge students to do critical thinking. In this study, the teachers used divergent questions, which allow students to analyze and create. Moreover, implementing group discussions can improve students' critical thinking. Samelian (2017) used discussion techniques, the students made discussion with peers, and another previous finding from Nuary (2015) showed that the teachers use discussion techniques and the process of discussion as follows: pre-discussion activities, while discussion activities and post discussion activities. The kinds of discussion are clarified into three components: discussion-based teaching; small group discussion; and classroom discussion. After the teaching and learning process, the teacher used the remaining time to give feedback and assess learning to ask the students to review, refine, and improve understanding of the material. At this stage, the findings are in line with Limbach \& Waugh (2010) who state the theory of reviewing, refining and improving understanding, and training feedback and assessing learning for critical thinking. Moreover, giving motivation to the students is needed. Bhushan (2014) states motivation is the main important factor that stimulates critical thinking and creativity. On the other hands, Hung, Durcikova, Lai, \& Lin (2011) note that critical thinking activities can empower students who are motivated to learn persistence when faced with a task; and the difficulty of a job will motivate students to learn how to get more involved. This strategy can stimulate the spirit of students to think critically in learning reading.

\section{METHOD}

This study employed a used mixed methods design, in which the researcher mixed or combined quantitative and qualitative methods of research in one study (Johnson, R. Buke \& Christensen, 2014). As this study aimed to describe the teachers' strategies in 
developing HOTS in teaching reading skills and the teachers' challenges in developing the strategies in teaching reading skills using HOTS, quantitative and qualitative approaches were used in the data collection and analysis. To survey the participants using random samples and to generalize statistics on populations, the quantitative approach is applied (Johnson, R. Buke \& Christensen, 2014). On the other hand, using a qualitative approach provides rich and in-depth data on the personal significance of the participants (Bogdan \& Biklen, 2007).

The study was carried out in Daerah Istimewa Yogyakarta, in 2019. The participants were 22 English teachers teaching in Junior High School. Since this study applied a mixed-method design, two groups of participants were involved in the two phases of data collecting. In the first phase, 35 English teachers were invited to participate in the survey, but only 22 were willing to volunteer as participants in the research. The survey was carried out when they did a teacher professional development workshop. To collect the data about the knowledge of using HOTS in teaching experience, the teachers' strategies in implementing HOTS, and the students' reading skills, the researcher asked the participants to fill out questionnaires through Google form. As Johnson, R. Buke \& Christensen (2014) describe, a questionnaire is a selfreport data collection tool that is used to obtain information on the research participants ' thoughts, feelings, attitudes, beliefs, perceptions, personalities, and behavioral intentions. The questionnaire designed was divided into two parts. In the first part, the questionnaire consisted of 20 items in the form of close-ended questions. The purpose of this questionnaire was to get a general overview of these participants. In the second part, the questionnaire consisted of two questions in the form of open-ended questions. The purpose was to describe their strategies and challenges in using HOTS. The data gathered through questionnaires were analyzed and specified to conduct deeper data collecting in the second phase. After analyzing the data based on the participants, the researcher chose four participants to join the next phase of the study. The researcher conducted a semi-structured interview. Ary et al. (2010) explain that an interview is used to collect people's data in their own words concerning opinions, beliefs, and feelings about situations. (p. 438). These five participants were chosen purposefully, meaning that the researcher should specify and locate the characteristics of participants of their interest. Moreover, the researcher has an opportunity to choose the participants whose experiences are interesting to be explored and fit with the purpose and focus of this study. Besides, the researcher also conducted an observation to observe five teachers in their teaching activities in the classroom. The researcher observes all relevant situations and took extensive field notes (Johnson, R. Buke \& Christensen, 2014).

In analyzing the data, the researcher used descriptive statistics to analyze the questionnaire. According to Johnson, R. Buke \& Christensen (2014), descriptive statistics allows the researcher to start with a set of data and to convey the important data characteristics into a more interpretable type. In the next step, the researcher analyzed the interviews and observations result using the coding analysis technique for the qualitative approach. The researcher combined the results of the interviews and the field notes and coded them into its label. Johnson, R. Buke \& Christensen (2014) argue that coding is a process of making text data with descriptive words (p. 534). 


\section{FINDINGS AND DISCUSSION}

The implementation of HOTS in teaching and learning reading skills is needed. The teacher should have some strategies in the teaching and learning process, especially when the teacher implemented HOTS. The researcher has done in distributing questionnaires and conducting an interview to find out some strategies in developing HOTS. The result of the questionnaires can be seen below.

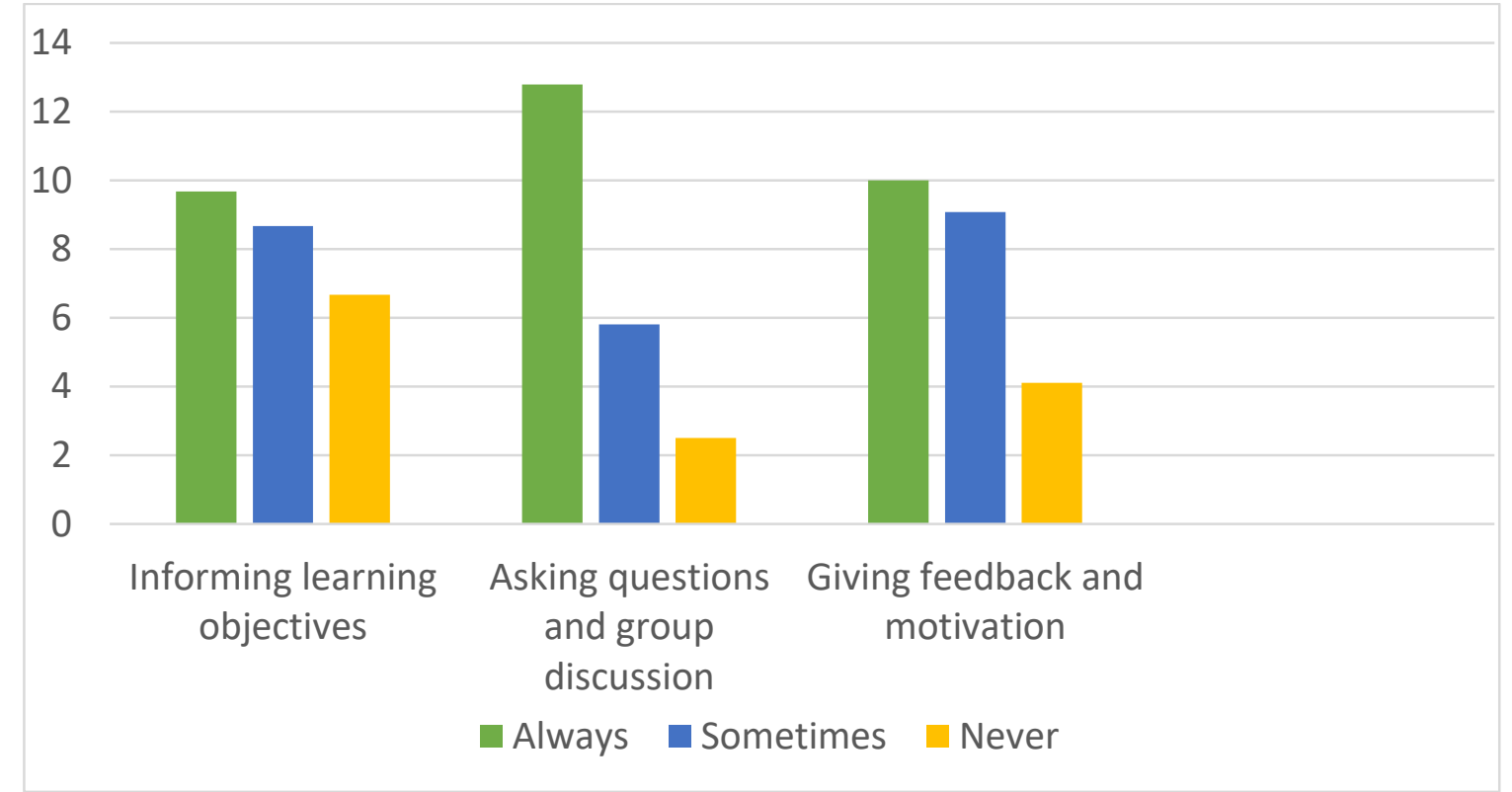

Figure 1. Teacher Strategies for developing HOTS in teaching reading skill.

In this part, the researcher explored the teachers' strategies for developing HOTS in teaching reading skills. The teachers' strategies were planned by the teachers to teach students in the class, especially in teaching-learning reading skills. Based on the diagram above, most teachers used some steps in teaching reading skills, such as informing learning objectives, asking questions to students, using group discussion, giving feedback, and giving motivation. The details of those strategies are clarified below.

\section{Informing learning objectives to students}

In the interview, the teachers explained that most teachers introduced the goals or purposes of the text at the beginning of the class. The researcher used procedure text as an example. The teachers discussed the goals of procedure text that is to describe how to make something. They also explained the goals of the discussion and presentation that was to improve students' ability in doing the role-play. Besides, students could work together in a group. Dahlia explained further:

"Procedure text is a text that gives us command or instruction for doing something or making something. Usually, this text begins with the sentence such as how to make a coffee, how to make smoothies, or how to operate the ATM machine. Then, the purpose of the procedure text itself is to explain how something is made, done, or used through consecutive steps. Have you understood?" (Dahlia, interview 5)

After that, the teachers explained the objectives of the discussion and presentation in teaching reading skills. It can be seen below: 
"Besides, today we will do group discussions to learn about procedure text. After that, you discuss and share in front of the class. This activity is to make you become more active and work together in making procedure text." (Ndari, interview 2)

The teacher informed the learning objectives in the teaching and learning process. The teacher used this step to apply HOTS in teaching the reading skill to develop critical thinking to brainstorm, analyze, and create procedure text in class. The purpose of informing learning objectives is students can appreciate procedure text and appreciate the technique used by the teacher. This finding is in line with the theory of Limbach \& Waugh (2010) who state that teachers should determine learning objectives to improve critical thinking before initiating the class.

\section{Encourage divergent questions}

Questioning is a process which the readers apply before, during, and after reading (Mckown \& Barnett, 2007). Based on the interview results, most teachers used divergent questions in their teaching strategies. The divergent question can make students analyze and create. The questions made students improve their skill in analyzing the procedure text delivered by the teacher. After analyzing, the students made the procedure text by own self.

a) Analyzing

In analyzing, the teacher gave a procedure text to the student and asked them to analyze the text after the teacher explaining the procedure text. It could be seen in the teaching and learning process as follow:

"Please do it, there is a procedure text. The title is how to make a lemon tea. Please analyze the three components. Discuss it with your group" (Arsi, interview 4)

According to the script above, the teacher ordered the students to analyze the procedure text with three questions. They were the ingredients or tools, the steps, and the goal of how to make a lemon tea.

b) Creating

The teacher gave questions again. The teacher ordered students to make some procedure texts after analyzing how to make lemon tea. The script is as follows:

"After you understand the procedure text, now make procedure text with your friend. Make sure that you have a different topic with other groups. You may write the text on your book" (Dahlia, interview 5)

Based on the interview above, the teacher ordered students to make procedure text after analyzing how to make a lemon tea. Then, the teacher recommended that the students have to do the assignment in their book. The teacher also permitted the students to discuss with other groups. However, cheating is strongly prohibited for students.

As (Harvey \& Goudvis, 2017) describe, the questioning process requires readers to ask themselves with critical questions to enhance understanding, construct meaning, solve problems, find answers, discover new information, and find information. Teachers used questions and answer strategies to review, examine learning, and challenge students to do critical thinking. The teachers also asked them to relate the materials with their own life. The higher-order questions from the teacher made students analyze and practice to write procedure text by themselves. Samelian (2017) states that HOTS could 
improve students' understanding of critical thinking skills and help them engage in high-level thinking to strengthen their understanding of reading comprehension skills. Likewise, Samelian's (2017) findings and these research findings also show the same kind of similarities. Samelian (2017) uses the storybook but the current study applied procedure texts. The findings corroborated with the theory of Limbach \& Waugh (2010) who state that teaching through question could develop students' critical thinking.

\section{Implementing Group Discussion}

The students can improve and be more active in the learning and teaching process by doing or creating something ordered by the teacher. The teacher instructed students to make procedure text after understanding the given procedure texts by analyzing and evaluating them. Then, if students finished the job, the teacher-directed the students to make a presentation in front of the class. The sample of the student-teacher dialogue can be seen below:

Teacher: After you understand the procedure text, now please make the procedure text with your friend. Make sure that you have a different topic with other groups. You may write the text on your book

Students: Yes Sir

Teacher: Then, present your results in front of the class

(After doing the assignments)

Teacher: Have you finished?

Students: Yes Sir

Teacher: Okay, Good. Now please present your results one by one in front of the class. Who wants to do it first? I will give you an additional score.

Based on the observation results above, after students have understood the explanation from the teacher, the teacher told them to make a procedure text by doing group discussions with their friends. After the discussion had finished, the teacher asked the students to come in front of the class and present their results one by one.

From the dialogue above, it is obvious that the teacher used discussions to train students to carry out text analysis procedures with their peers. After students finished working on the assignments given by the teacher, the students must present their work one by one. In previous findings from Samelian (2017) also uses discussion technique, the students made discussion with the peers, and another previous finding from Nuary (2015) that the teacher used discussion technique and the discussion process is as follows: pre-discussion activities and post-discussion activities. The types of discussion are: (a) discussion-based teaching; (b) small group work; (c) classroom discussion. The current findings and previous findings were found similarities and differences. Besides, Limbach \& Waugh (2010) state, the teacher instructs students to practice. Then the theory by (Vacca, 2014) that teaching or reciprocal discussion by teachers to students or students to other people discuss something can help the students understand the material. Based on the theory from Burt et al (2003), if the teacher wanted to use this method or strategy it is better to add a group discussion because group discussions will further develop students' thinking by exchanging ideas and giving opinions to each other new things students receive in class. Moreover, group discussions or small group discussions can improve students to actively participate, be more confident, and increase their motivation in joining reading classes (Siswanti \& Setyaningsih, 2012). 
The previous findings and the current findings had similarities and differences in the teacher used a discussion technique.

\section{Giving feedback to students}

After the teaching and learning process, the teacher used the remaining time to give feedback and assess learning to ask the students to review, refine, and improve understanding of the material. That is showed in the teaching and learning process below.

"Now please exchange your result with the other groups. Then, check your friends' results. Check the topic first. Is it the same or not. Please check also the components of the procedure text. Is it suitable to the topic or not. Please give mark if there is something wrong or something that makes you confused in reading the text. Then, please exchange again until you get feedback from 3 other groups at least." (Dahlia, interview 5)

The teacher asked the students to discuss with their group about the similarities and differences in the students' assignment. The teacher required the students to present the results of the discussion in front of the class. It was aimed to improve the student's feedback and assessing whether the class learning goal was achieved.

Table 1. Classroom observation result, 5 August 2019

\begin{tabular}{|c|c|c|}
\hline Category & Activities & \\
\hline Review & $\begin{array}{l}\text { Teacher } \\
\text { Student }\end{array}$ & $\begin{array}{l}\text { : Before we end our class today, I will ask you for } \\
\text { the last question. What have you learned today? } \\
\text { : I have learned procedure text Miss }\end{array}$ \\
\hline \multirow[t]{8}{*}{ Refine } & Teacher & $\begin{array}{l}\text { : Good. Could you give an example of a procedure } \\
\text { text? }\end{array}$ \\
\hline & Student & : Orange Juice Miss \\
\hline & Teacher & : Yes, Good. Please make it complete. \\
\hline & Teacher & : Yes, you? \\
\hline & Student & $\begin{array}{l}\text { : How to make Orange Juice, Miss. } \\
\text { (Student said with wrong pronunciation) }\end{array}$ \\
\hline & Teacher & $\begin{array}{l}\text { That is correct. Please say with the correct } \\
\text { pronunciation, how to make an orange juice (read } \\
\text { with correct pronunciation). Then, what is a } \\
\text { procedure text? }\end{array}$ \\
\hline & Student & : The text is useful for instructing something Miss \\
\hline & Teacher & $\begin{array}{l}\text { : Yes, that is correct. Great job. The text is to give } \\
\text { information about how to make something }\end{array}$ \\
\hline \multirow[t]{5}{*}{$\begin{array}{l}\text { Improve } \\
\text { Understanding }\end{array}$} & Teacher & $\begin{array}{l}\text { Yes, that is correct. The text is to giving } \\
\text { information how to make something. Then the } \\
\text { procedure text has three components. What are } \\
\text { they? }\end{array}$ \\
\hline & Student & : Ingredients, steps, and goals Miss \\
\hline & Teacher & : What are the ingredients? \\
\hline & naterials or & $\begin{array}{l}\text { ects used to make or } \\
\text { operate something, Miss }\end{array}$ \\
\hline & Teacher & : Yes, correct. Good job everyone. \\
\hline
\end{tabular}


Before the lesson was finished, the teacher invited students to review, refine and improve the students' understanding of the material that had been previously discussed. The details are presented in Table 1.

Based on the observation results above, in reviewing the materials, the teacher asked what students learned during the lesson. Then when refining the students' understanding, the teacher asked students what a procedure text is and how it is useful to provide understanding to students. The teacher asked questions about the composition of procedure text to further enhance students' understanding of the components of the procedure text so that students did not get confused later on.

The teacher provided feedback to students and invited students to review, refine, and improve understanding before learning is over. The teacher-reviewed the material with students, and students became more active rather than the teacher. After reviewing the material in each section, the teacher improved the materials in the class with students. The aim is to improve students' skills to criticize the material by ensuring students to understand the material to the fullest. Then the teacher carried out the learning value for the students during the review, refine, and improve stages. These stages are to understand students' abilities or skills on how successful the strategies are for the students. At this stage, the findings are in line with Limbach \& Waugh's (2010) theory on reviewing, refining, improving understanding, training feedback, and assessing learning for critical thinking.

\section{Giving Motivation to think critically}

Motivation is very important for teachers to students. If the teachers can create an encouraging situation in the class, this helps the teacher to leverage the students' motivation. The participants explained that they frequently give motivation when teaching in the class. That statement is from the interview dialog as follows:

"In every learning, we frequently motivate the students by giving encouragement and praise when they can work on the questions given; sometimes also by giving them rewards in the form of additional scores or objects that could be useful for students while studying at school or home." (Ana, interview 3)

In the interview above, the teacher said that she frequently gives motivation to students in the teaching and learning process. The teacher gave motivation with encouraging words when the student could answer or finish the job from the teacher; sometimes the teacher also gave a reward like something useful for learning. In the observation, the teachers motivated the students in the teaching and learning process:

Teacher : Okay ... now I will answer the question later and it must be explained if I really give a plus, anyone knows what a step is?

Teacher : Yes, what?

Student : ee... that means the process or steps to make lemon tea, the first one that boils the water is Miss...

Teacher : Good. You are smart... what is your name?

Student : Rina miss

Teacher : Okay, I marked it

Student : Yeay..

(Classroom observation, 5 August 2019)\ 
From the classroom observation above, the teacher gave a challenge to the students. If they can answer the question, the teacher gave more scores to the student. Therefore, the student had more motivation to answer the question, as well as more motivation to think critically about the material.

Bhushan (2014) argues that motivation is the main important factor that stimulates critical thinking and creativity. The teacher motivated the students to think critically in the teaching-learning process by giving a question about procedure text. If students could answer the questions correctly, they would get praise from the teacher and be given an additional score from the teacher, or sometimes the teacher gave rewards in the form of a difference that can be used to study at school or home. Hung et al. (2011) emphasize that critical thinking activities can empower students who are motivated to learn persistence when faced with task difficulties. The challenges of an assignment will motivate students to learn how to get more involved. This strategy can stimulate the spirit of students to think critically in learning how to read.

\section{CONCLUSIONS}

The implementation of HOTS in teaching and learning reading skills is needed because it is one of the requirements in the 2013 curriculum. The English teachers should also have available strategies in the teaching and learning process, especially when they implemented HOTS. Based on the interview and questionnaire results, most teachers used the following steps in teaching reading skills: (1) informing learning objectives to students; (2) encourage divergent questions; (3) implementing group discussion; (4) giving feedback to students; and, (5) giving motivation to think critically.

The findings revealed that the teachers informed the learning objectives in the learning and teaching process. The teachers used this step to apply HOTS in teaching the reading skill to develop critical thinking to analyze and make procedure text in class. Then, teachers asked questions to make students active and have critical thinking skills in understanding something in a new context. Samelian (2017) states that higher-order questions and critical thinking can improve understanding and supporting students in high-level thinking to strengthen their comprehension of reading. Besides, the teachers can use discussions to train students to carry out text analysis procedures with their peers. After that, the teacher provided feedback to students and invited students to review, refine, and improve understanding before the learning episode is over. Likewise, the teachers also motivate students to think critically by asking questions. Those strategies above were applied by the teachers and help students in developing their critical thinking.

This study was carried with some limitations because it only investigated the teachers' strategies using HOTS in teaching reading skills. The study did not cover and explore the teachers' challenges in developing HOTS in teaching reading and students' responses about those strategies. Further research on this field can include the teachers' challenges in coping with the problems for developing those strategies and at the same time looking into the students' responses on the outcomes of its problems and solutions.

\section{References}

Aloqaili, A. S. (2012). The relationship between reading comprehension and critical thinking: A theoretical study. Journal of King Saud University - Languages and Translation, 24(1), 35-41. https://doi.org/10.1016/j.jksult.2011.01.001 
Alsowat, H. (2016). An EFL flipped classroom teaching model: Effects on English language higher-order thinking skills, student engagement and satisfaction. Journal of Education and Practice, 7(9), 108-121.

Ariyana, Y., Bestary, R., \& Mohandas, R. (2018). Buku pegangan pembelajaran berorientasi pada ketrampilan berpikir tingkat tinggi. Jakarta: Direktorat Jenderal Guru dan Tenaga Kependidikan Kementerian Pendidikan dan Kebudayaan.

Arnuphab. (2007). Effects of English reading instruction based on the reader response approach on critical reading ability and critical thinking ability of upper secondary school students. Chulalongkom University.

Ary, Donald., Jacobs, Lucy Cheser., Sorensen, Chris., Razavieh, A. (2010). Introduction to research in education ( $8^{\text {th }} \mathrm{ed}$; C. Shortt, Ed.). Wadsworth: Cengage Learning.

Barkhuizen, G. (2017). Reflections on Language Teacher Identity Research. In Reflections on Language Teacher Identity Research. https://doi.org/10.4324/9781315643465

Bhushan, R. (2014). Developing Learner's Critical Thinking and Motivation. International Journal on Studies in English Language and Literature (IJSELL), 2(6), 11-16. Retrieved from www.arcjournals.org

Bogdan, R. C., \& Biklen, S. K. (2007). Research for education: An introduction to theory and methods. Boston: Allen and Bacon.

Brookhart, S. M. (2010). How to assess higher-order thinking skills in your classroom. Alexandria, Virginia: ASCD. Retrieved from www.ascd.org

Burt, M., Peyton, J. K., Linguistics, A., States, U., \& Adams, R. J. (2003). Reading and adult english language learners: A review of the research. Washington, DC: Center for Applied Linguistics.

Day, R., \& Bamford, J. (2002). Top ten principles for teaching extensive reading. Reading in a Foreign Language, 14(2), 136.

Grabe, W. (2010). Fluency in Reading - Thirty-Five Years Later. Reading in a Foreign Language, 22(1), 71-83.

Harvey, S., \& Goudvis, A. (2017). Visualizing and Inferring: Making What's Implicit Explicit. In Strategies that work: Teaching comprehension for understanding engagement and building knowledge ( ${ }^{\text {rd }}$ ed, pp. 151-184). Portland, Maine: Stenhouse Publishers.

Heong, Y. M., Othman, W. B., Yunos, J. Bin, Kiong, T. T., Hassan, R. Bin, Mohaffyza, M., \& Mohamad, B. (2011). The Level of Marzano Higher Order Thinking Skills among Technical Education Students. International Journal of Social Science and Humanity, 1(2), 121-125.

Hung, S., Durcikova, A., Lai, H., \& Lin, W. (2011). The influence of intrinsic and extrinsic motivation on individuals ' knowledge sharing behavior. Journal of Human Computer Studies, 69(6), 415-427. https://doi.org/10.1016/j.ijhcs.2011.02.004

Johnson, R. B. \& Christensen, L. (2014). Educational research: Quantitative, qualitative, and miexed approaches $\left(5^{\text {th }} \mathrm{ed}\right)$. Thousand Oaks: SAGE Publications, Inc.

Kistner, S., Rakoczy, K., Otto, B., \& Klieme, E. (2015). Teaching learning strategies : The role of instructional context and teacher beliefs. Journal for Educational Research Online, 7(1), 176-197.

Kulekci \& Kumlu. (2015). Developing Critical Thinking Skills in English Language Teaching Classes Through Novels. International Journal of Language Academy, 3, 76-90. https://doi.org/http://dx.doi.org/10.18033/ijla.222 
Lee, K., \& Lai, Y. (2017). Facilitating higher-order thinking with the flipped classroom model: A student teacher's experience in a Hong Kong secondary school. Research and Practice in Technology Enhanced Learning, 12(1), 8. https://doi.org/10.1186/s41039-017-0048-6

Leung, K. H. (2008). Higher Order Thinking in Online Courses. In Handbook of Research on Instructional System and Technology (pp. 785-802). Hershey, Pennsylvania: IGI Global.

Limbach, B., \& Waugh, W. (2010). Developing Higher Level Thinking. Journal of Instructional Pedagogies, 9. Retrieved February 2018 from https://aabri.com/manuscripts/09423.pdf

Marina, L., Acosta, E., \& Ferri, M. M. (2015). Reading strategies to develop higher thinking skills for reading comprehension. Profile Issues in Teachers Professional Development, 12(1), 107-123.

Mckown, B. A., \& Barnett, C. L. (2007). Improving Reading Comprehension through Higher-Order Thinking Skills. Saint Xavier University.

Nuary, C. (2015). The Implementation of Discussion in Teaching Reading at Seventh Grade of SMP Murni 1 Surakarta. Muhammadiyah Surakarta University.

Peña, A. N., \& Cañón, J. M. (2008). Developing cognitive processes in teenagers through the reading of short story. Profile Issues in Teachers Professional Development, 9, 9-22.

Samelian, L. A. (2017). How Higher Order Questioning and Critical Thinking Affects Reading Comprehension (Hamline University). Retrieved from http://digitalcommons.hamline.edu/hse_all

Savich, C. (2009). Improving Critical Thinking Skills in History. An On-Line Journal for Teacher Research, 11(2).

Seman, S. C., Yusoff, W. M. W., \& Embong, R. (2017). Teachers Challenges in Teaching and Learning for Higher Order Thinking Skills (HOTS) in Primary School. International Journal of Asian Social Science, 7(7), 534-545. https://doi.org/10.18488/journal.1.2017.77.534.545

Siswanti, F., \& Setyaningsih, N. (2012). The Use of Small-Group Discussion to Improve Students' Reading Comprehension. English Education, 2(2), 216-232.

Vacca, R. T. (2014). From Efficient Decoders to Strategic Readers. Educational Leadership, 60(3), 6-11.

Williams, J. D., \& Takaku, S. (2011). Help seeking, self-efficacy and writing performance among college students. Journal of Writing Research, 3(2011), 1-18. https://doi.org/http://dx.doi.org/10.17239/jowr- 2011.03.01.1

Yeung, S. S. (2016). Conception of teaching higher order thinking: Perspectives of Chinese teachers in Hong Kong. The Curriculum Journal, 26(4), 553-578. https://doi.org/10.1080/09585176.2015.1053818 